\title{
SILICON SOURCES FOR RICE CROP
}

\author{
Hamilton Seron Pereira ${ }^{1 *}$; Gaspar Henrique Korndörfer²; Anelisa de Aquino Vidal3; Mônica \\ Sartori de Camargo ${ }^{2}$ \\ ${ }^{1}$ UFG - Campus Avançado de Jataí, Centro de Ciências Agrárias e Biológicas. Rod BR 364, km 192, Zona Rural \\ - 75800-000 - Jataí, GO - Brasil. \\ ${ }^{2}$ UFU - Instituto de Ciências Agrárias, C.P. 593 - 38400-902 - Uberlândia, MG - Brasil. \\ ${ }^{3}$ UFU - Programa de Pós-Graduação em Agronomia. \\ *Corresponding author <hsp@jatai.ufg.br>
}

\begin{abstract}
Although silicon is not an essential nutrient, its application is beneficial for plant growth and development. To evaluate silicon sources in relation to agronomic efficiency and economic viability in rice crops (Oryza sativa L.), a greenhouse experiment was conducted, Quartzipsamment soil, in a completely randomized experimental design $(n=4)$. Treatments were 12 silicon sources and a control. Silicon was applied at the rate of $125 \mathrm{~kg} \mathrm{Si} \mathrm{ha}^{-1}$. Data were compared to a standard response curve for Si using the standard source Wollastonite at rates of $0,125,250,375$, and $500 \mathrm{~kg} \mathrm{Si} \mathrm{ha}^{-1}$. All treatments received $\mathrm{CaCO}_{3}$ and $\mathrm{MgCO}_{3}$ to balance $\mathrm{pH}, \mathrm{Ca}$ and $\mathrm{Mg}$. One hundred and fifty days after sowing, evaluations on dry matter yield in the above-ground part of plants, grain yield, and Si contents in the soil and plant tissues were performed. Wollastonite had linear response, increasing silicon in the soil and plants with increasing application rates. Differences between silicon sources in relation to Si uptake were observed. Phosphate slag provided the highest Si uptake, followed by Wollastonite and electric furnace silicates which however, did not show differed among themselves. The highest Si accumulation in grain was observed for stainless steel, which significantly differed from the control, silicate clay, Wollastonite, and AF2 (blast furnace of the company 2) slag. Silicate clay showed the lowest Si accumulation in grain and did not differ from the control, AF2 slag, AF1 slag, schist ash, schist, and LD4 (furnace steel type LD of the company 4) slag.
\end{abstract}

Key words: slag, metallurgical aggregate, silicate, oryza

\section{FONTES DE SILÍCIO PARA A CULTURA DO ARROZ}

\begin{abstract}
RESUMO: O silício, mesmo não sendo essencial do ponto de vista fisiológico, traz inúmeros benefícios para o crescimento e o desenvolvimento das plantas. Com o objetivo de avaliar diferentes fontes de Si quanto à disponibilidade do nutriente para plantas de arroz (Oryza sativa L.), foi realizado um experimento em Neossolo Quartzarênico Órtico típico, em casa-de-vegetação em delineamento inteiramente casualizado com doze fontes de silício aplicadas na dose de $125 \mathrm{~kg} \mathrm{Si} \mathrm{ha}^{-1}$ e uma testemunha $(\mathrm{n}=4)$. Dados experimentais foram comparados a uma curva padrão de resposta para silício, utilizando a fonte padrão (Wollastonita) nas doses de 0, 125, 250, 375 e $500 \mathrm{~kg} \mathrm{Si} \mathrm{ha}^{-1}$. Visando equilibrar os valores de $\mathrm{pH}$, Ca e Mg, todos os tratamentos foram balanceados com $\mathrm{CaCO}_{3}$ e $\mathrm{MgCO}_{3}$. Após 150 dias do plantio, foi avaliada a produção de matéria seca da parte aérea, produção de grãos e teores de Si no solo e nas plantas. A Wollastonita, usada como fonte padrão, apresentou comportamento linear, aumentando o Si disponível no solo, conseqüentemente, a absorção pelo arroz com o aumento nas doses aplicadas. A fonte que proporcionou maior absorção de Si pelas plantas de arroz foi a escória de fósforo, seguida da Wollastonita e de forno elétrico que não diferiram entre si. A fonte Aço Inox foi a que apresentou maior extração de Si pelos grãos, diferindo da testemunha, da argila silicatada, da Wollastonita e da escória AF2 (alto-forno da empresa 2). A fonte de silício que apresentou a menor liberação no solo e extração pelas plantas foi a argila silicatada, pois não diferiu da testemunha, seguido da escória AF2, AF1, da Cinza de xisto, do Xisto e da escória LD4 (forno de aciaria tipo LD da empresa 4).

Palavras-chave: escórias, agregado siderúrgico, silicato, oryza
\end{abstract}

\section{INTRODUCTION}

The importance of Si fertilization in rice (Oryza sativa L.) and sugarcane (Saccharum spp.), among other crops, has already been demonstrated by Okuda \& Takahashi (1964) in Japan; Ayres (1966) and Halais (1968) in Mauritius; Gascho (1978), Snyder et al.
(1986), and Anderson et al. (1987) in Florida; and Korndörfer et al. (2002) in Brazil. The critical sufficiency levels of this element in the soil and plants are currently being established in Brazil (Korndörfer et al., 1999; 2002). It is therefore necessary to identify the most promising, potentially available Si sources to plants. 
Plant residues, such as rice hulls and sugarcane bagasse, are sometimes used as Si sources. In addition to the fact that they are slow-release Si sources, these residues have other uses, such as the generation of steam, and are insufficient to meet the demand for $\mathrm{Si}$ in agriculture. On the other hand, there are Si-rich metallurgic slags which could meet this demand. The high temperatures used in iron industry release Si from crystalline form to reactive and consequently more soluble forms.

Analyzing results of 23 field experiments, during the 1992-1996 period, Korndörfer et al. (2001) observed increase in grain yield of irrigated rice - 1,007 $\mathrm{kg} \mathrm{ha}^{-1}$ in plots receiving $\mathrm{Si}$ as Ca silicate. On the other hand, accumulated $\mathrm{Si}$ in rice plants could reduce transpiration rate, by decreasing water intake (Marschner, 1995 and Takahashi, 1996). Results by Faria (2000) corroborate this assertion; when soil moisture was at $80 \%$ of field capacity, no increases in grain yield were observed. Conversely, under a lower soil humidity value - $60 \%$ of field capacity - grain yield increased were linearly with increasing Si rates, an indication that Si plays important role on increasing tolerance of rice plants to water stress.

The most important characteristics of a Si source for agricultural use are: high soluble Si content, suitable physical properties, easy mechanized application, ready availability for plants, low cost, balanced ratios and amounts of calcium (Ca) and magnesium (Mg), and absence of heavy metals. Many iron metallurgy slags possess these traits, and some of them are promising sources of Si (Korndörfer et al., 2002).
Considering the lack of information and the great demand for agronomically efficient and economically viable Si sources for agriculture purpose, the objective here was to evaluate several Si-rich materials (slags, silicates, thermophosphates etc.) with regard to their ability to supply this element to plants.

\section{MATERIAL AND METHODS}

Experiment was set up in a greenhouse in a potted rice crop (5 kg dry soil per pot), with subsurface samples of a Quartzipsamment with low soluble Si content in acetic acid $0.5 \mathrm{~mol} \mathrm{dm}^{-3}$. The chemical attributes of the soil used in the experiment were: $\mathrm{pH}\left(\mathrm{CaCl}_{2} 0.01\right.$ mol L ${ }^{-1}$ ) 4.4; P $56 \mathrm{mg} \mathrm{dm}^{-3}$ (extracted by $\mathrm{H}_{2} \mathrm{SO}_{4} 0.025$ mol $\left.\mathrm{dm}^{-3}+\mathrm{HCl} 0.05 \mathrm{~mol} \mathrm{dm}^{-3}\right)$; Si $3.3 \mathrm{mg} \mathrm{dm}^{-3} ; \mathrm{Al} 10$ $\mathrm{mmol}_{\mathrm{c}} \mathrm{dm}^{-3}$; Ca $2 \mathrm{mmol}_{\mathrm{c}} \mathrm{dm}^{-3}$; $\mathrm{Mg} 1 \mathrm{mmol}_{\mathrm{c}} \mathrm{dm}^{-3}$; sum of bases $4 \mathrm{mmol}_{\mathrm{c}} \mathrm{dm}^{-3}$; effective CEC $14 \mathrm{mmol}_{\mathrm{c}} \mathrm{dm}^{-3}$; CEC $52 \mathrm{mmol}_{\mathrm{c}} \mathrm{dm}^{-3}$; V (\%) 7; m (\%) 71; and organic matter $15 \mathrm{~g} \mathrm{~kg}^{-1}$.

The experiment was set up in a completely randomized design and the sources used were defined as a function of their potential for agricultural use and Si-supplying capacity. Materials were characterized with regard to their origin, total $\mathrm{Si}, \mathrm{Ca}$, and $\mathrm{Mg}$ contents, and Neutralizing Power (NP) (Table 1). Wollastonite a product with high degree of purity used worldwide in studies involving Si was used as standard source for comparisons. The slag samples were dried and sifted through a 50-mesh screen.

Table 1 - Characteristics of Si sources studied and amounts applied in treatments.

\begin{tabular}{|c|c|c|c|c|c|c|c|c|}
\hline Treatment & $\mathrm{SiO}_{2}$ & $\mathrm{CaO}$ & $\mathrm{MgO}$ & calc. $\mathrm{NP}^{(1)}$ & det. NP & Product Dose & $\mathrm{CaCO}_{3} \mathrm{Dose}^{(2)}$ & $\mathrm{MgCO}_{3}$ Dose $^{(2)}$ \\
\hline & $-\cdots$ & $\mathrm{g} \mathrm{kg}$ & $-\cdots--$ & $\ldots \% \mathrm{E} \mathrm{Ca}$ & $\mathrm{CO}_{3}^{(3)}-.-$ & - & -- g per pot & $-\cdots-1$ \\
\hline Control & - & - & - & - & - & - & 12.66 & 2.28 \\
\hline Wollastonite & 503 & 424 & 1.9 & 76 & 74 & 2.66 & 10.75 & 2.27 \\
\hline Blast Furnace Slag 1 - AF $1^{(4)}$ & 384 & 301 & 75.2 & 73 & 70 & 3.49 & 10.88 & 1.72 \\
\hline Blast Furnace Slag 2 - AF2 & 334 & 425 & 52.3 & 89 & 88 & 4.01 & 9.77 & 1.83 \\
\hline $\mathrm{LD}^{(5)}$ furnace steel slag 1 - LD1 & 123 & 409 & 72.7 & 91 & 91 & 10.91 & 5.11 & 0.58 \\
\hline LD furnace steel slag 2 - LD2 & 109 & 282 & 76.1 & 69 & 96 & 12.28 & 6.81 & 0.28 \\
\hline LD furnace steel slag $3-$ LD3 & 174 & 395 & 95.5 & 94 & 103 & 7.71 & 7.51 & 0.70 \\
\hline LD furnace steel slag 4 - LD4 & 112 & 276 & 28.5 & 57 & 92 & 11.97 & 7.07 & 1.55 \\
\hline Phosphorus solub. slag & 461 & 435 & 6.8 & 80 & 63 & 2.91 & 10.52 & 2.24 \\
\hline Silicate clay & 480 & 22 & 191.4 & 52 & 33 & 3.13 & 12.29 & 1.56 \\
\hline AOD furnace steel slag & 101 & 564 & 57.8 & 115 & 119 & 13.28 & 0.00 & 0.63 \\
\hline Electric furnace steel slag & 158 & 257 & 125.7 & 77 & 95 & 8.46 & 8.98 & 0.00 \\
\hline Stainless steel slag & 232 & 367 & 94.3 & 89 & 88 & 5.77 & 9.08 & 1.11 \\
\hline Schist & 530 & 20 & 16 & 4 & 4 & 2.6 & 12.6 & 2.3 \\
\hline Schist ash & 624 & 24 & 19 & 5 & 5 & 2.2 & 12.6 & 2.3 \\
\hline
\end{tabular}

${ }^{(1)} \mathrm{NP}=$ neutralization power, calculated and determined respectively of Si sources; ${ }^{(2)} \mathrm{CaCO}_{3}$ and $\mathrm{MgCO}_{3}$ dose to balance the Ca and $\mathrm{Mg}$ contents applied with treatments; ${ }^{(3)} \% \mathrm{E} \mathrm{CaCO}_{3}=$ equivalent percentage in $\mathrm{CaCO}_{3}$ of $100 \mathrm{~g}$ of product; ${ }^{\left({ }^{3}\right)} \mathrm{AF} 1$ and $\mathrm{LD} 1$ = material of the company 1; AF2 and LD2 = material of the company 2; LD3 = material of the company 3; and LD4 = material of the company 4; ${ }^{(5)}$ Designation given to the type of furnace used to convert iron into steel. 
Treatments were applied as presented in Table 1. Additional treatments with 250, 375, and $500 \mathrm{~kg} \mathrm{ha}^{-1}$ Si were applied using the standard (Wollastonite) in order to obtain the Si absorption curves by the plants. The soil was moistened up to $70 \%$ of field capacity. The incubation period lasted 40 days, and by the end of January, 2001, the rice crop (Formoso variety) was planted.

Plants nutritional requirements were met by 100 $\mathrm{mL}$ of a nutritive solution containing $1.43 \mathrm{~g} \mathrm{dm}^{-3}$ urea, 1 $\mathrm{g} \mathrm{dm}^{-3}\left(\mathrm{NH}_{4}\right)_{2} \mathrm{SO}_{4}, 0.15 \mathrm{~cm}^{3} \mathrm{dm}^{-3} \mathrm{H}_{3} \mathrm{PO}_{4}, 1.56 \mathrm{~g} \mathrm{dm}^{-3} \mathrm{KCl}$, $4 \mathrm{~cm}^{3} \mathrm{dm}^{-3}$ of a micronutrient solution $\left(2.86 \mathrm{~g} \mathrm{dm}^{-3}\right.$ $\mathrm{H}_{3} \mathrm{BO}_{3}, 1.67 \mathrm{~g} \mathrm{dm}^{-3} \mathrm{MnSO}_{4} \cdot \mathrm{H}_{2} \mathrm{O}, 0.40 \mathrm{~g} \mathrm{dm}^{-3}$ $\mathrm{ZnSO}_{4} .7 \mathrm{H}_{2} \mathrm{O}, 0.10 \mathrm{~g} \mathrm{dm}^{-3} \mathrm{CuSO}_{4} .5 \mathrm{H}_{2} \mathrm{O}$, and $0.04 \mathrm{~g} \mathrm{dm}^{-3}$ $\mathrm{NH}_{4} \mathrm{MoO}_{4} \cdot 2 \mathrm{H}_{2} \mathrm{O}$ ), and $4 \mathrm{~cm}^{3} \mathrm{dm}^{-3}$ of EDTA iron solution, applied weekly to each pot.

After the third leaf was formed, pots were inundated with water $(1 \mathrm{~cm})$ and thinning was performed to set 20 plants per pot. At 150 days, the above-ground part of plants was harvested. Dry matter and grain yield, silicon uptake (dry matter and grain) were determined according to Elliott \& Snyder (1991), and soil silicon extracted by acetic acid $0.5 \mathrm{~mol} \mathrm{dm}^{-3}$ (Korndörfer et al., 1999) and $\mathrm{CaCl}_{2}$ $0.0025 \mathrm{~mol} \mathrm{dm}^{-3}$ (Raij \& Camargo, 1973). Si determination in the different soil extracts was performed by beta molybdosilicic complex formation (Kilmer, 1965).

Data were submitted to analyses of variance (F test) and means comparison test (Tukey test; $\alpha=0.05$ ). A polynomial regression was used to determine effects of Wollastonite doses. The equivalent dose of the standard source for each treatment was determined by applying the equation obtained from $\mathrm{Si}$ accumulation in the above-ground part of plants as a function of Wollastonite doses.

\section{RESULTS AND DISCUSSION}

There was a linear effect of Wollastonite application in the above-ground part of plants and grain, i.e., the higher the Si dose applied, the higher the concentration in the tissues (Figure 1).

When sources were compared, differences were observed between them. The phosphorus slag elicited the highest Si concentration in the above-ground part of plants, followed by Wollastonite and the electric furnace slag, which did not differ between themselves, for both above-ground part and grain. The stainless steel slag, LD3 and AOD only differed regarding Si content in the above-ground part. The source showing the smallest Si content was silicate clay, which did not differ from the control treatment, followed by AF2, AF1, schist ash, schist, and LD4 (Table 2).

Sci. Agric. (Piracicaba, Braz.), v.61, n.5, p.522-528, Sept./Oct. 2004
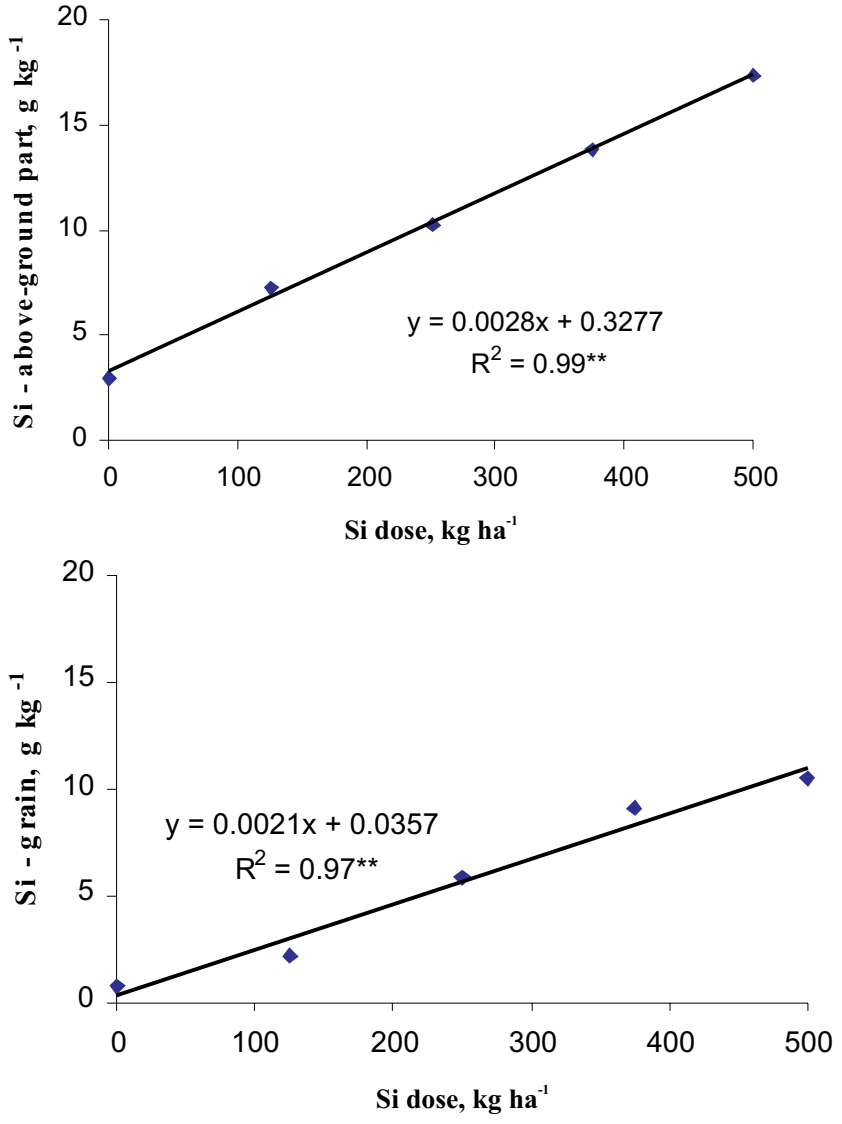

Figure 1 - Si contents in the above-ground part and grain of a rice crop as a function of Si doses supplied by the standard source (Wollastonite).

Table 2 - Si content in the above-ground part of rice plants and rice grain.

\begin{tabular}{lcc}
\hline Si Sources & Above-ground part ${ }^{(1)}$ & Grain $^{(1)}$ \\
\hline & $3.0 \mathrm{hi}$ & $0.7 \mathrm{c}$ \\
\hline Control & $7.2 \mathrm{ab}$ & $2.1 \mathrm{ac}$ \\
Wollastonite & $4.5 \mathrm{eh}$ & $3.1 \mathrm{ac}$ \\
\hline Blast Furnace Slag 1 - AF1 & $3.3 \mathrm{hi}$ & $1.8 \mathrm{bc}$ \\
Blast Furnace Slag 2 - AF2 & $5.5 \mathrm{ce}$ & $3.7 \mathrm{ab}$ \\
LD furnace steel slag 1 - LD1 & $5.4 \mathrm{cf}$ & $3.5 \mathrm{ab}$ \\
LD furnace steel slag 2 - LD2 & $6.0 \mathrm{bd}$ & $3.6 \mathrm{ab}$ \\
\hline LD furnace steel slag 3 - LD3 & $4.9 \mathrm{dg}$ & $2.7 \mathrm{ac}$ \\
LD furnace steel slag 4 - LD4 & $7.7 \mathrm{a}$ & $4.4 \mathrm{a}$ \\
Phosphorus solub. Slag & $6.1 \mathrm{bd}$ & $4.0 \mathrm{ab}$ \\
Stainless steel slag & $6.7 \mathrm{ac}$ & $3.8 \mathrm{ab}$ \\
Electric furnace steel slag & $6.0 \mathrm{be}$ & $2.8 \mathrm{ac}$ \\
AOD furnace steel slag & $2.7 \mathrm{i}$ & $2.5 \mathrm{ac}$ \\
Silicate clay & $3.9 \mathrm{fi}$ & $2.7 \mathrm{ac}$ \\
Schist & $3.7 \mathrm{gi}$ & $2.7 \mathrm{ac}$ \\
\hline Schist ash & 12.0 & 33.1 \\
\hline C.V. (\%) & 1.6 & 2.5 \\
\hline msd 5\% & & \\
\hline (1)Means followed by the same letter in the column do not differ by \\
Tukey (P < 0.05). & & \\
\hline
\end{tabular}


Steel slags (LD, AOD, electric, and stainless steel furnaces) had higher Si availability than blast furnace slag, and those slags also showed solubility differences among themselves, depending on the type of steel produced and type of furnace used to produce steel (Table 2). Similar results were also obtained by Kato \& Owa (1997).

The soil Si content determined by both extractors also increased with Wollastonite doses (Figure 2), but extraction in acetic acid was higher. With regard to results of soil Si and Si accumulated by plants, no significant correlations were found (Figure 3).

The AF2 slag was the source with the highest $\mathrm{Si}$ release by acetic acid (Table 3), but it was not, however, the treatment with the greatest uptake by the plant; actually, the opposite occurred. This happened due to Si solubility in the source itself by acetic acid. A similar fact occurs with phosphorus extracted by double acid in soils where natural phosphate is applied. Results overestimate this element because of the insoluble phosphorus solubilization in the soil by the acid (Raij, 1991). On the contrary, high correlation between soil Si extracted in acetic acid and plant-absorbed Si was observed when Wollastonite was applied, since it is practically insoluble in weak acid (Pereira et al., 2003). In this case, Si determined in the soil corresponds to the amount of Si actually released by the source.
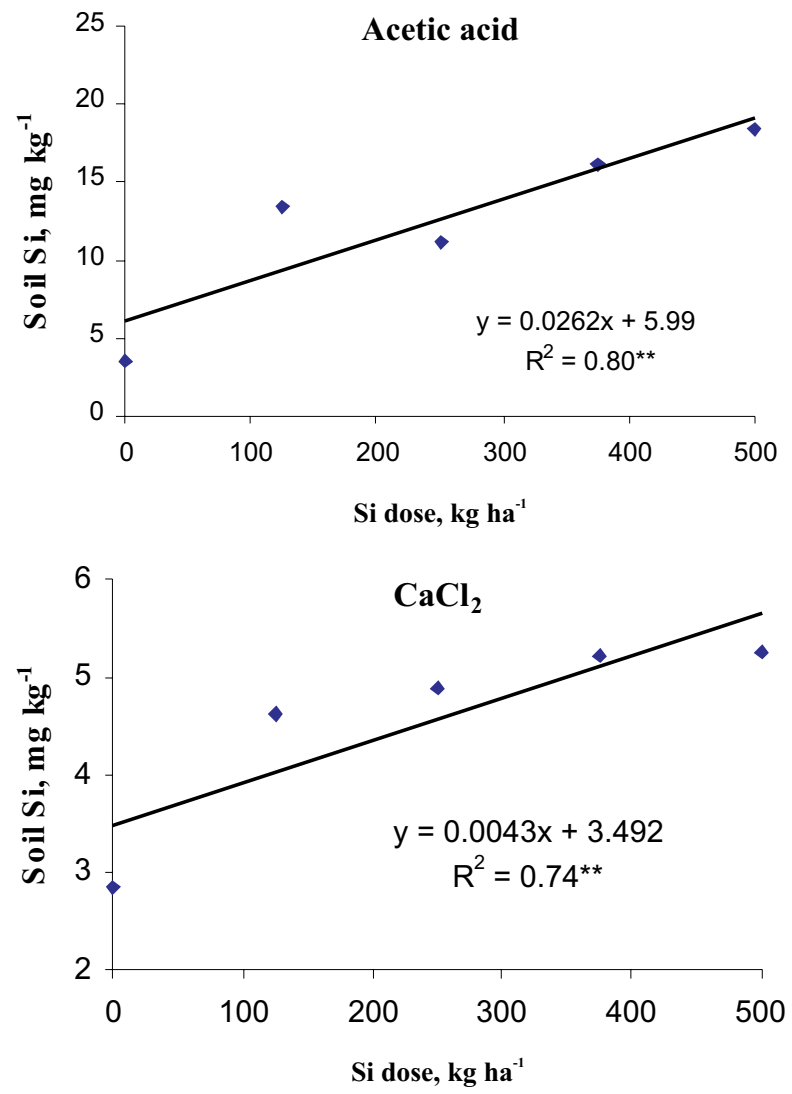

Figure 2 - Soil Si contents extracted with acetic acid and calcium chloride as a function of Si doses supplied by the standard source (Wollastonite).
$\mathrm{CaCl}_{2}$, the $\mathrm{Si}$ in the soil, extracted by showed better correlation when compared to the acetic acid, contradicting results of Korndörfer et al. (1999) who, working with a single Si source, concluded that acetic acid is superior to calcium chloride. Some Si sources show solubility in acetic acid but not in $\mathrm{CaCl}_{2}$. Therefore, acetic acid could solubilize the material applied to the soil, which is not available for plants, overestimating Si availability. This was demonstrated in another paper by Korndörfer \& Gascho (1999). When different doses of Wollastonite and phosphorus slag were applied, the authors observed greater Si accumulation in rice with Wollastonite, while the source with the highest $\mathrm{Si}$ release in the soil was phosphorus slag.

With respect to dry matter yield, Wollastonite showed linear increase with increasing Si doses (Figure 4). This reinforces the idea that $\mathrm{Si}$ is indeed beneficial to rice. However, the only difference between sources occurred for grain yield between the stainless steel (highest yield) and silicate clay treatments (lowest yield) (Table 4). Maybe the $125 \mathrm{~kg} \mathrm{ha}^{-1}$ dose was not sufficient to reveal more expressive differences between sources. In the case of Wollastonite, the response was linear and positive with increasing doses, with the application of $500 \mathrm{~kg}$ $\mathrm{ha}^{-1} \mathrm{Si}$ showing the highest yield (Figure 4).
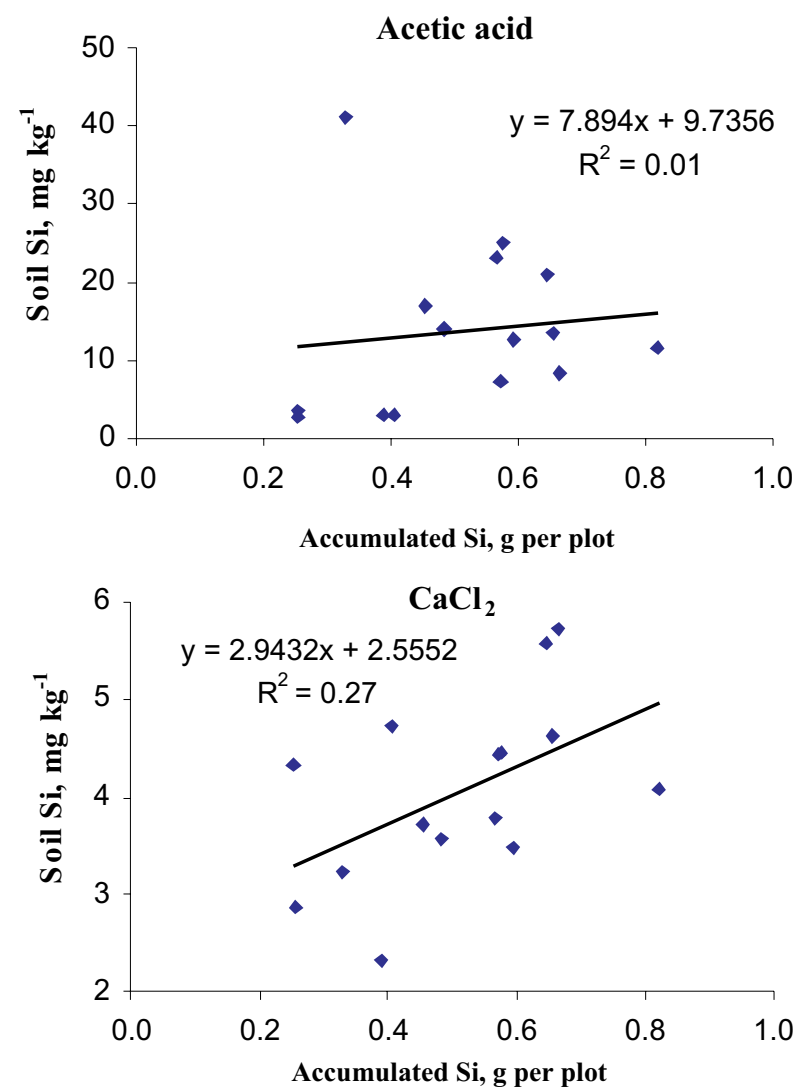

Figure 3 - Correlation between Si extracted from the soil with acetic acid and calcium chloride and Si accumulated by rice plants. 
Table 3 - Si contents in the soil determined in $0.5 \mathrm{~mol} \mathrm{dm}{ }^{-3}$ acetic acid and $0.025 \mathrm{~mol} \mathrm{dm}{ }^{-3} \mathrm{CaCl}_{2}, 190$ days after application of different Si sources.

\begin{tabular}{lcc}
\hline Si Sources & $\begin{array}{c}\text { Acetic acid- } \\
\text { extracted } \mathrm{Si}^{(1)}\end{array}$ & $\begin{array}{c}\mathrm{CaCl}_{2} \text {-extract- } \\
\mathrm{ed} \mathrm{Si}\end{array}$ \\
\hline Control & $3.0 \mathrm{hi}$ & $0.7 \mathrm{c}$ \\
Wollastonite & $7.2 \mathrm{ab}$ & $2.1 \mathrm{ac}$ \\
Blast Furnace Slag 1 - AF1 & $4.5 \mathrm{eh}$ & $3.1 \mathrm{ac}$ \\
Blast Furnace Slag 2 - AF2 & $3.3 \mathrm{hi}$ & $1.8 \mathrm{bc}$ \\
LD furnace steel slag 1 - LD1 & $5.5 \mathrm{ce}$ & $3.7 \mathrm{ab}$ \\
LD furnace steel slag 2 - LD2 & $5.4 \mathrm{cf}$ & $3.5 \mathrm{ab}$ \\
LD furnace steel slag 3 - LD3 & $6.0 \mathrm{bd}$ & $3.6 \mathrm{ab}$ \\
LD furnace steel slag 4 - LD4 & $4.9 \mathrm{dg}$ & $2.7 \mathrm{ac}$ \\
Phosphorus solub. Slag & $7.7 \mathrm{a}$ & $4.4 \mathrm{a}$ \\
Stainless steel slag & $6.1 \mathrm{bd}$ & $4.0 \mathrm{ab}$ \\
Electric furnace steel slag & $6.7 \mathrm{ac}$ & $3.8 \mathrm{ab}$ \\
AOD furnace steel slag & $6.0 \mathrm{be}$ & $2.8 \mathrm{ac}$ \\
Silicate clay & $2.7 \mathrm{i}$ & $2.5 \mathrm{ac}$ \\
Schist & $3.9 \mathrm{fi}$ & $2.7 \mathrm{ac}$ \\
Schist ash & $3.7 \mathrm{gi}$ & $2.7 \mathrm{ac}$ \\
\hline C.V. (\%) & 12.0 & 33.1 \\
\hline msd 5\% & 1.6 & 2.5 \\
\hline
\end{tabular}

(1) Means followed by the same letter in the column do not differ by Tukey test at $5 \%$.
With regard to Si extraction by plants, Wollastonite also showed linear increases with increasing doses (Figure 5). Between sources, P slag also accumulated the most Si, followed by Wollastonite, which differed in $\mathrm{Si}$ accumulation in the grain, and by electric furnace slag, which differed in Si accumulation in dry matter. These two sources, however, did not differ regarding total Si uptake (Table 5).

Stainless steel slag was the source allowing the higher Si acumulation in grain due to its higher productivity, and was the source ranked fourth regarding total Si uptake, followed by LD1, LD3, AOD, LD2, and LD4. The sources extracting the smallest amount of Si were, again, silicate clay and AF2, which also did not differ from the control, followed by schist, schist ash, and AF1 (Table 5).

When the efficiency of the sources with regard to total Si accumulation was considered in comparison to the standard, P slag was the only source superior to the standard. Stainless steel slag and electric furnace slag were seemingly as efficient as the standard, while the other iron metallurgy slags (LD1, LD3, AOD, and LD2) showed a behavior where reduced doses of the standard, between 10 and 20\%, would be enough to provide the same amount of $\mathrm{Si}$ as the $125 \mathrm{~kg} \mathrm{ha}^{-1} \mathrm{Si}$ doses provided by those sources. The other sources showed equivalent doses well below that value; the least effi-
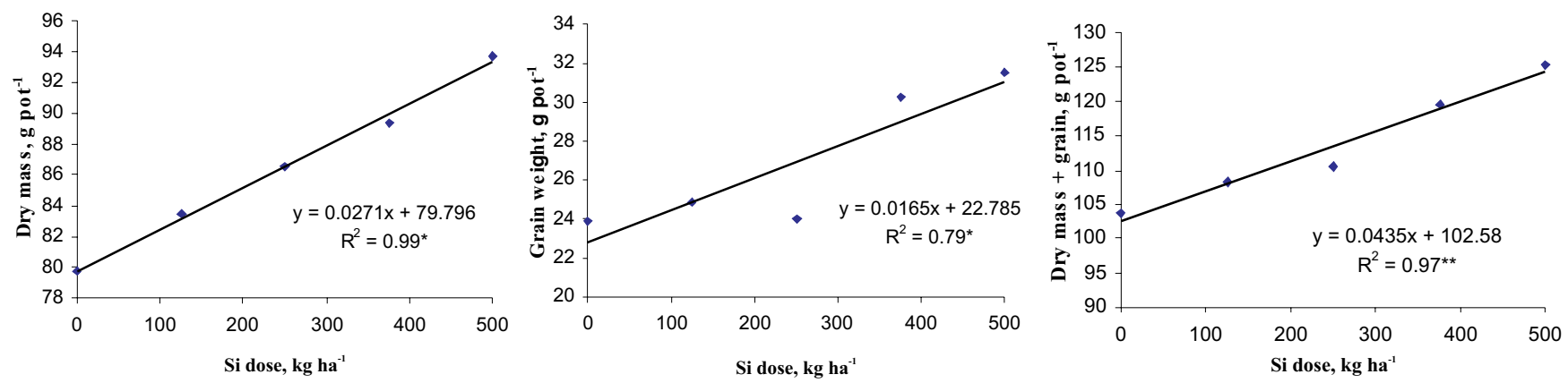

Figure 4 - Effect of Si doses (Wollastonite) on dry matter yield and rice grain yield.
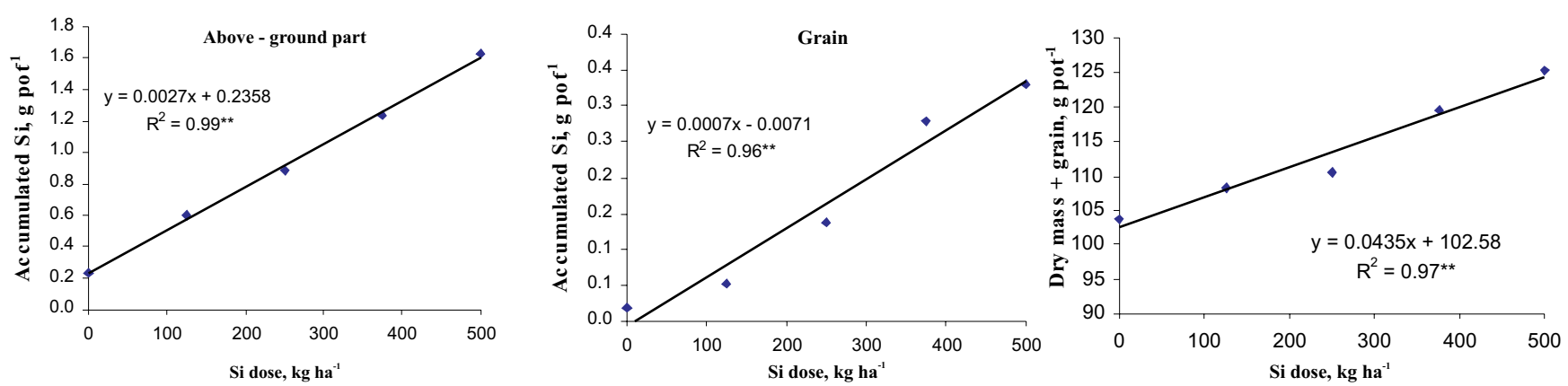

Figure 5 - Si extraction in the above-ground part of a rice crop as a function of Si doses supplied by the standard source (Wollastonite). 
Table 4 - Effect of Si sources on dry mass yield, grain yield, and total rice yield.

\begin{tabular}{|c|c|c|c|}
\hline Si Sources & Dry mass yield & Grain yield $^{(1)}$ & Total yield (above-ground part + grain) \\
\hline & --- & 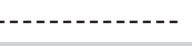 & pot -- \\
\hline Control & 79.7 & $23.9 \mathrm{ab}$ & 103.7 \\
\hline Wollastonite & 83.4 & $24.9 \mathrm{ab}$ & 108.3 \\
\hline Blast Furnace Slag 1 - AF1 & 86.2 & $21.5 \mathrm{ab}$ & 107.7 \\
\hline Blast Furnace Slag 2 - AF2 & 87.0 & $24.3 \mathrm{ab}$ & 111.3 \\
\hline LD furnace steel slag 1 - LD1 & 89.3 & $26.4 \mathrm{ab}$ & 115.6 \\
\hline LD furnace steel slag 2 - LD2 & 89.2 & $24.8 \mathrm{ab}$ & 114.1 \\
\hline LD furnace steel slag 3 - LD3 & 81.6 & $23.9 \mathrm{ab}$ & 105.6 \\
\hline LD furnace steel slag 4 - LD4 & 84.6 & $25.5 \mathrm{ab}$ & 110.2 \\
\hline Phosphorus solub. slag & 91.8 & $24.1 \mathrm{ab}$ & 115.9 \\
\hline Stainless steel slag & 83.3 & $33.5 \mathrm{a}$ & 116.9 \\
\hline Electric furnace steel slag & 86.4 & $24.4 \mathrm{ab}$ & 110.8 \\
\hline AOD furnace steel slag & 84.8 & $24.8 \mathrm{ab}$ & 109.6 \\
\hline Silicate clay & 79.0 & $15.5 \mathrm{~b}$ & 94.5 \\
\hline Schist & 83.5 & $26.5 \mathrm{ab}$ & 109.9 \\
\hline Schist ash & 91.1 & $25.9 \mathrm{ab}$ & 117.0 \\
\hline C.V. (\%) & 7.5 & 19.2 & 8.3 \\
\hline msd $5 \%$ & 16.3 & 12.0 & 23.2 \\
\hline
\end{tabular}

${ }^{1}$ Means followed by the same letter in the column do not differ by Tukey test at $5 \%$.

Table 5 - Silicon accumulated in the above-ground part of rice plants and equivalent Si doses supplied by the standard source to obtain the same amount of total Si accumulated by rice from other sources.

\begin{tabular}{|c|c|c|c|c|}
\hline \multirow[b]{2}{*}{ Si Sources } & \multicolumn{4}{|c|}{ Rice-accumulated $\mathrm{Si}^{(1)}$} \\
\hline & $\begin{array}{l}\text { Above-ground part } \\
\text { (no grain })^{(1)}\end{array}$ & Grain $^{(1)}$ & Total (above-ground part + grain) $)^{(1)}$ & $\begin{array}{l}\text { Equivalent dose to standard } \\
\text { source (Wolastonite) }{ }^{(1)}\end{array}$ \\
\hline & - n-n & ---1 & per pot & $\mathrm{Si}, \mathrm{kg} \mathrm{ha}^{-1}$ \\
\hline Control & $0.24 \mathrm{e}$ & $0.02 \mathrm{c}$ & $0.25 \mathrm{~g}$ & 0 \\
\hline Wollastonite & $0.60 \mathrm{ab}$ & $0.05 \mathrm{bc}$ & $0.66 \mathrm{ab}$ & 125 \\
\hline Blast Furnace Slag 1 - AF 1 & $0.38 \mathrm{~cd}$ & $0.07 \mathrm{ac}$ & $0.45 \mathrm{df}$ & 66 \\
\hline Blast Furnace Slag 2 - AF2 & $0.29 \mathrm{de}$ & $0.04 \mathrm{bc}$ & $0.33 \mathrm{fg}$ & 30 \\
\hline LD furnace steel slag 1 - LD1 & $0.49 \mathrm{bc}$ & $0.10 \mathrm{ab}$ & $0.59 \mathrm{bd}$ & 107 \\
\hline LD furnace steel slag 2 - LD2 & $0.48 \mathrm{bc}$ & $0.08 \mathrm{ac}$ & $0.57 \mathrm{be}$ & 99 \\
\hline LD furnace steel slag 3 - LD3 & $0.49 \mathrm{bc}$ & $0.08 \mathrm{ac}$ & $0.58 \mathrm{bd}$ & 102 \\
\hline LD furnace steel slag 4 - LD4 & $0.42 \mathrm{~cd}$ & $0.07 \mathrm{ac}$ & $0.48 \mathrm{cf}$ & 75 \\
\hline Phosphorus solub. slag & $0.71 \mathrm{a}$ & $0.11 \mathrm{ab}$ & $0.82 \mathrm{a}$ & 174 \\
\hline Stainless steel slag & $0.51 \mathrm{bc}$ & $0.13 \mathrm{a}$ & $0.64 \mathrm{bc}$ & 122 \\
\hline Electric furnace steel slag & $0.57 \mathrm{~b}$ & $0.09 \mathrm{ac}$ & $0.66 \mathrm{ab}$ & 128 \\
\hline AOD furnace steel slag & $0.50 \mathrm{bc}$ & $0.07 \mathrm{ac}$ & $0.57 \mathrm{bd}$ & 101 \\
\hline Silicate clay & $0.21 \mathrm{e}$ & $0.04 \mathrm{bc}$ & $0.25 \mathrm{~g}$ & 7 \\
\hline Schist & $0.32 \mathrm{de}$ & $0.07 \mathrm{ac}$ & $0.39 \mathrm{fg}$ & 47 \\
\hline Schist ash & $0.34 \mathrm{de}$ & $0.07 \mathrm{ac}$ & $0.41 \mathrm{eg}$ & 52 \\
\hline C.V. $(\%)$ & 12.48 & 39.47 & 12.54 & \\
\hline msd 5\% & 0.14 & 0.07 & 0.16 & \\
\hline
\end{tabular}

(1)Means followed by the same letter in the column do not differ by Tukey test at $5 \%$.

cient was again silicate clay, where the supplying of only $7 \mathrm{~kg} \mathrm{ha}^{-1}$ Si provided by the standard would be sufficient to show the same effect as $125 \mathrm{~kg} \mathrm{ha}^{-1}$ Si provided by this source.

\section{REFERENCES}

ANDERSON, D.R.; JONES, D.B.; SNYDER, G.H. Response of a ricesugarcane rotation to calcium silicate slag on Everglades Histosols. Agronomy Journal, v.79, p.531-535, 1987. 
AYRES, A.S. Calcium silicate slag as a growth stimulant for sugarcane on low-silicon soils. Soil Science, v.101, p.216-227, 1966.

ELLIOTT, C.L.; SNYDER, G.H. Autoclave-induced digestion for the colometric determination of silicon in rice straw. Journal of the Agriculture and Food and Chemistry, v.39, p.1118-1119, 1991.

FARIA, R. Efeito da acumulação de silício e a tolerância das plantas de arroz do sequeiro ao déficit hídrico do solo. Lavras: UFLA, 2000. 98p. (Dissertação - Mestrado).

GASCHO, G.J. Response of sugarcane to calcium silicate slag. I. Mechanisms of response in Florida. Soil Crop Science Society, v.37, p.55-57, 1978.

HALAIS, P. Silicon, calcium and manganese contents of cane leaf sheaths collected on ten great soil groups in Mauritius. In: CONGRESS OF THE INTERNATIONAL SOCIETY OF SUGAR CANE TECHNOLOGY, 13., Taiwan, 1968. Proceedings. Taiwan: Society Sugar Cane Technology, 1968. p.756-762.

KATO, N.; OWA, N. Evaluation of Si availability in slag fertilizers by an extraction method using a cation exchange resin. Soil Science and Plant Nutrition, v.43, p.351-359, 1997.

KILMER, V.J. Silicon. In: BLACK, C.A. (Ed.) Methods of soil analysis. Madison: ASA, 1965. pt.1, p.959-962. (Agronomy, 9).

KORNDÖRFER, G.H.; PEREIRA, H.S.; CAMARGO, M.S. Papel do silício na produção da cana-de-açúcar. STAB Açúcar e Álcool e Subprodutos, v.21, p.6-9, 2002.

KORNDÖRFER, G.H.; GASCHO, G.J. Avaliação de fontes de silício para o arroz. In: CONGRESSO BRASILEIRO DE ARROZ IRRIGADO, 1.; REUNIÃO DA CULTURA DO ARROZ IRRIGADO, 23., Pelotas, 1999. Anais. Pelotas: Embrapa Clima Temperado, 1999, p.313-316.

KORNDÖRFER, G.H.; COELHO, N.M.; SNYDER, G.H.; MIZUTANI, C.T. Avaliação de métodos de extração de silício para solos cultivados com arroz de sequeiro. Revista Brasileira de Ciência do Solo, v.23, p.101106, 1999.
KORNDÖRFER, G.H.; SNYDER, G.H.; ULLOA, M.; POWELL, G.; DATNOFF, L.E. Calibration of soil and plant silicon analysis for rice production. Journal of Plant Nutrition, v.24, p.1071-1084, 2001.

KORNDÖRFER, G.H.; PEREIRA, H.S.; CAMARGO, M.S. Papel do silício na produção da cana-de-açúcar. STAB Açúcar e Álcool e Subprodutos, v.21, p.6-9, 2002.

MARCHNER, H. Mineral nutrition of higher plants. 2.ed. London: Academic Press, 1995. 889p.

OKUDA, A.; TAKAHASHI, E. The role of silicon: In: SYMPOSIUM OF THE INTERNATIONAL RICE RESEARCH INSTITUTE, Baltimore, 1964. The mineral nutrition of the rice plant. Baltimore: John Hopkins Press, 1964. p.123-146.

PEREIRA, H.S.; KORNDÖRFER, G.H.; MOURA, W.F.; CORREA, G.F. Extratores de silício disponível em escórias e fertilizantes. Revista Brasileira de Ciência do Solo, v.27, p.265-274, 2003.

RAIJ, B. van. Fertilidade do solo e adubação. Piracicaba: Agronômica Ceres; Associação Brasileira para a Pesquisa da Potassa e do Fosfato, 1991. 343p.

RAIJ, B. van; CAMARGO, O.A. Sílica solúvel em solos. Bragantia, v.32, p.223-236, 1973.

SNYDER, G.H.; JONES, D.B.; GASCHO, G.J. Silicon fertilization of rice on Everglades Histosols. Soil Science Society of America Journal, v.50, p.1259-1263, 1986.

TAKAHASHI, E. Uptake mode and physiological functions of silica. In: TAKAHASHI, E.; HOSHIKAWA, K. (Ed.) Science of the rice plant: Physilogy. Tokyo: Food and Agriculture Policy Research Center, 1996. v.2, p.420-433.

Received February 09, 2004

Accepted August 12, 2004 